\title{
WCRF-AICR Continuous Update Project: Systematic Literature Review of Prospective Studies on Circulating 25-hydroxyvitamin D and Kidney Cancer Risk
}

The Journal of Steroid Biochemistry and Molecular Biology

Andrea L. Darling, Leila Abar and Teresa Norat

Department of Epidemiology and Biostatistics, School of Public Health, Faculty of Medicine, Imperial College, St Mary's Campus, Norfolk Place, London W2 1PG, UK

andrea.darling@imperial.ac.uk / a.I.darling@surrey.ac.uk

l.abar@imperial.ac.uk

t.norat@imperial.ac.uk

Corresponding Author: Dr Andrea L. Darling ${ }^{1}$

1Present address: Dr Andrea L. Darling: Postdoctoral Research Fellow, Department of Nutritional Sciences, School of Biosciences and Medicine, Dorothy Hodgkin Building, University of Surrey, Guildford, GU2 7XH. +0044 (0)1483 689222. a.l.darling@surrey.ac.uk

Running Title: Circulating 25-hydroxyvitamin D and Kidney Cancer Risk

\section{Author post print copy:}

Cite this article in press as A.L.Darling, L.Abar, T.Norat. WCRF-AICR Continuous Update Project: Systematic Literature review of prospective studies on circulating 25-hydroxyvitamin D and kidney cancer risk. J Steroid Biochem. Mol. Biol. (2015),http://dx.doi.org/10.1016/j.jsbmb.2015.10.001 Publisher version at http://www.sciencedirect.com/science/article/pii/S0960076015301035

This copy is released under a creative commons attribution non-commercial, no derivatives license. 
This work was funded as part of the World Cancer Research Fund International/American Institute for Cancer Research (WCRF/AICR) Continuous Update Project (Grant Number 2007/SP01) (TN and LA). ALD was funded by the Imperial College National Institute of Health Research (NIHR) Biomedical Research Centre (BRC).

The views expressed in this review are the opinions of the authors. The views may not represent the views of World Cancer Research Fund International/American Institute for Cancer Research (WCRF/AICR) and may differ from those in future updates of the evidence related to food, nutrition, physical activity, and cancer risk. The sponsor of this study had no role in the decisions about the design or conduct of the study; collection, management, analysis, or interpretation of the data; or preparation, review, or approval of the manuscript.

Conflict of Interest:

None of the authors reported a conflict of interest related to the study

Manuscript notes:

Word count=2139 (excluding references); 2 figures and 1 table

Author declaration:

ALD, LA and TN all contributed to the revision of and approval of the manuscript and had full access to all study data. Specifically, the literature search and data extraction was undertaken by $L A$, with data extraction checked in duplicate by ALD. The systematic review analysis was conducted by ALD and interpreted by ALD and TN. The first version of the manuscript was written by ALD and co-authors contributed to the final version. ALD holds responsibility for the integrity and accuracy of the data analysis and the final results. TN is the Continuous Update Project primary investigator and supervised the systematic review process. 


\section{Abstract}

As part of the World Cancer Research Fund/ American Institute for Cancer Research (WCRFAICR) Continuous Update project we performed a systematic review of prospective studies with data for both measured or predicted $25(\mathrm{OH}) \mathrm{D}$ concentration and kidney cancer risk. PubMed was searched from inception until 1st December 2014 using WCRF/AICR search criteria.

The search identified 4 papers suitable for inclusion, reporting data from three prospective cohort studies, one nested case-control study and the Vitamin D Pooling Project of Rarer Cancers (8 nested case-control studies). Summary effect sizes could not be computed due to incompatibility between studies. All studies except the Pooling Project suggested a reduced risk of kidney cancer by $19-40 \%$ with higher or adequate vitamin D status, . However, these estimates only reached statistical significance in one cohort (Copenhagen City Heart Study; CCHS, HR=0.75 (0.58 to 0.96)). In the European Prospective Investigation into Cancer and Nutrition (EPIC) study, a significant reduction in risk by $18 \%$ was seen when using combined matched and non-matched controls $\mathrm{OR}=0.82(0.68,0.99)$, but not when using only matched controls $(\mathrm{OR}=0.81(0.65,1.00)$. Pooled (but not single cohort) data for predicted $25(\mathrm{OH}) \mathrm{D}$ from the Nurses' Health Study (NHS) and Health Professionals Follow-up Study (HPFS) showed a statistically significant reduction in risk by $37 \%(\mathrm{HR}=0.63(0.44,0.91))$.

There is no clear explanation for the inconsistency of results between studies, but reasons may include prevalence of smoking or other study population characteristics. Methods for assessing circulating 25(OH)D levels and control for confounders including seasonality or hypertension do not seem explanatory.

Keywords: Kidney Cancer, 25-hydroxyvitamin D, Systematic Review, Vitamin D, Nutrition 


\section{Highlights}

- A systematic review of studies assessing 25(OH)D status and kidney cancer risk.

- Four cohort or nested case-control studies and one Pooling Project were included.

- Subject populations and smoking prevalence may explain between cohort differences.

- An association between low 25(OH)D and kidney cancer risk could not be ruled out. 


\subsection{Introduction}

Kidney cancer is the $14^{\text {th }}$ most frequent cancer worldwide ${ }^{1}$ with renal cell carcinoma the most common type. Incidence rates increased until the middle of the 1990s and then stabilized, but recent estimates suggest that in some countries incidence rates are still increasing ${ }^{2}$. These trends might have been influenced by the use of new imaging tests and the changing prevalence of known risk factors including smoking and obesity ${ }^{3}$.

The kidneys are the main tissue in the body responsible for hydroxylation of the circulating metabolite $25(\mathrm{OH}) \mathrm{D}$ to the active hormone 1,25-dihydroxyvitaminD $\left(1,25(\mathrm{OH})_{2} \mathrm{D}\right)$. Most kidney cancers are of epithelial cell origin, and vitamin D has known beneficial anti-neoplastic properties in human epithelium ${ }^{4}$. An inverse relationship has been found between occupational UVB exposure and renal cell carcinoma risk in men, which could be partly attributable to vitamin $D$ status ${ }^{5}$. In this systematic review we assessed the evidence from prospective studies on vitamin D status and kidney cancer risk, examining potential sources of heterogeneity between studies. 


\subsection{Materials and Methods}

\subsection{Search Strategy and Study Selection}

The search criteria and data extraction protocol used were those used in the WCRF/AICR

Continuous Update Project (full protocol available at http://wcrf.org/sites/default/files/protocol_kidney_cancer.pdf). Two reviewers independently selected the articles and extracted the data for the most highly adjusted model reported in each paper for renal cell carcinoma or kidney cancer. Figure 1 illustrates the flow of articles through the selection process. Four articles were relevant for inclusion containing data on three cohort studies (Copenhagen City Heart Study $(\mathrm{CCHS})^{6}$, Nurses' Health Study (NHS), Health Professionals Follow-Up Study $(\mathrm{HPFS})^{7}$, a nested case-control study (European Prospective Investigation into Cancer and Nutrition (EPIC) ${ }^{8}$ and the Pooling Project of Rarer Cancers $^{9}$, which included 8 nested case control studies (see Table 1 for details). A report from the Alpha-Tocopherol Beta-Carotene Cancer Prevention Study (ATBC) ${ }^{10}$ was excluded as this cohort was already included in the Pooling Project ${ }^{9}$. Circulating $25(\mathrm{OH}) \mathrm{D}$ was assessed from serum or plasma samples in all studies except the NHS and HPFS ${ }^{7}$ whereby $25(\mathrm{OH}) \mathrm{D}$ was predicted using validated regression models that included major determinants of vitamin D status.

FIGURE 1 ABOUT HERE

\subsection{Data analysis}

Study results were tabulated and shown in a forest plot. Summary estimates were not calculated due to the differences in the increment units and contrasts used in the studies. Contrasts chosen for inclusion in the forest plot were those closest to the well-established $25(\mathrm{OH})$ D cut off points of $>75 \mathrm{nmol} / \mathrm{L}^{11}$ for optimal vitamin $\mathrm{D}$ status, compared to $<25 \mathrm{nmol} / \mathrm{L}$ 
(referent) for vitamin D deficiency. It must be borne in mind that these cut-off points have much debated in vitamin D literature. For the Pooling $\operatorname{Project}^{9}$ (combined male and female estimate) the reference category was changed to $<25 \mathrm{nmol} / \mathrm{L}$ and the top two categories combined to produce a cut-off point of $\geq 75 \mathrm{nmol} / \mathrm{L}$, using the method described by Hamling et al. $(2008)^{12}$. Two studies (CCHS, EPIC) presented the data for continuous increments of $25(\mathrm{OH}) \mathrm{D}$ and are also shown in the same forest plot. To increase the comparability across study results, the $\mathrm{HR}$ of the CCHS data ${ }^{6}$ was recalculated to increments of doubling of $25(\mathrm{OH}) \mathrm{D}$ levels (originally expressed for reduction). 


\subsection{Results}

Study characteristics are shown in Table 1. Overall, the studies on measured 25(OH)D concentration included 1390 kidney cancer or renal cell carcinoma cases. From these, 775 kidney cancer cases are from the Vitamin D Pooling Project of Rarer Cancers, 55 cases are from the CCHS and 560 renal cell carcinoma cases are from EPIC. In the Vitamin D Pooling Project, the results for kidney cancer and renal cell carcinomas were similar. In all studies, 25(OH)D was measured in only a single blood sample. The NHS and HPFS cohorts ${ }^{7}$ used predicted plasma $25(\mathrm{OH}) \mathrm{D}$ and included 408 cancer cases.

\section{TABLE 1 ABOUT HERE}

Figure 2 illustrates the forest plot of predicted or actual plasma vitamin D and kidney cancer. The Pooling Project ${ }^{9}$ did not support an association of circulating $25(\mathrm{OH}) \mathrm{D}$ concentration with the risk of RCC, with an odds ratio of $1.18(95 \% \mathrm{Cl} 0.63,2.22)$ for the $\geq 75 \mathrm{nmol} / \mathrm{L}$ as compared with $<25 \mathrm{nmol} / \mathrm{L}$ (referent), and an odds ratio of $1.12(0.79,1.59)$ for $25(\mathrm{OH}) \mathrm{D}$ concentration $<37.5 \mathrm{nmol} / \mathrm{L}$, as compared with $50-75 \mathrm{nmol} / \mathrm{L}$ (referent)(data not shown in the Figure). For continuous data, in the $\mathrm{CCHS}^{6}$ lower plasma $25(\mathrm{OH}) \mathrm{D}$ was significantly related with a higher risk of kidney cancer ${ }^{6}$. The Hazard ratio for a $50 \%$ reduction in plasma 25(OH)D was 1.34 $(1.04,1.73)$. Equivalent data for a $50 \%$ increase in plasma $25(\mathrm{OH}) \mathrm{D}$ was estimated as 0.75 $(0.58,0.96)$. In the EPIC study ${ }^{8}$ a doubling of $25(\mathrm{OH}) \mathrm{D}$ concentration was associated with a reduced odds of developing RCC of $0.82(0.68,0.99)$ in the combined control model (data not shown in the Figure 2), and $0.81(0.65,1.00)$ for the matched control model ${ }^{8}$.

For the studies on predicted vitamin D score, there was a non-statistically significant trend for a reduced risk of RCC by $40 \%$ in the NHS (women; $H R=0.60(0.35,1.02)$ and by $34 \%$ in the HPFS (men; HR=0.66 $(0.40,1.09)$ for the top quintile of predicted $25(\mathrm{OH}) \mathrm{D}$ versus the lowest quintile (referent) ${ }^{7}$. Pooled results from the NHS and HPFS showed a statistically significant reduction in risk of $\mathrm{RCC}$ by $37 \%\left(\mathrm{HR}=0.63(0.44,0.91)\right.$ for equivalent quintiles ${ }^{7}$ (data not 
shown). In continuous analyses, the HR per $10 \mathrm{ng} / \mathrm{mL}(25 \mathrm{nmol} / \mathrm{L})$ of predicted $25(\mathrm{OH}) \mathrm{D}$ were $0.61(0.35,1.04)$ in the HPFS cohort, $0.70(0.45,1.07)$ in the NHS cohort ${ }^{7}$ and $0.66(0.47$ to 0.92) (ptrend=0.009) for both combined.

\section{FIGURE 2 ABOUT HERE}

Sub-analyses undertaken in the Pooling Project showed that women with the highest 25(OH)D (i.e. $75 \mathrm{nmol} / \mathrm{L}$ or over) have a significantly reduced risk of all kidney cancer than women with $25(\mathrm{OH}) \mathrm{D}$ of $50-74 \mathrm{nmol} / \mathrm{L}^{9}$. However, this effect was not statistically significant when $<25 \mathrm{nmol} / \mathrm{L}$ (referent) was compared with $\geq 75 \mathrm{nmol} / \mathrm{L}$ (Table 1). However, there was no effect modification by sex in the EPIC study ${ }^{8}$, and in the cohorts with predicted circulating 25(OH)D scores (NHS and HPFS), similar inverse associations were observed in men and women. 


\subsection{Discussion}

This systematic review showed inconsistent evidence as to whether kidney cancer risk is related to vitamin D status. No association was observed in the Pooling Project of Rarer Cancers $^{9}$. A significant inverse association with kidney cancer was observed in the CCHS ${ }^{6}$ (only 55 kidney cancer cases) and in EPIC, lower risk of renal cell carcinoma was observed with a doubling of circulating $25(\mathrm{OH}) \mathrm{D}$ concentration, but only when combined controls rather than matched controls were used. Also, when combined, the two studies using predicted 25(OH)D scores (NHS and HPFS) showed significant inverse association with kidney cancer risk. However, results were not statistically significant for the two cohorts separately.

The reasons for the different results between cohorts are unclear. In EPIC ${ }^{8} 25(\mathrm{OH}) \mathrm{D}_{3}$ was determined by liquid chromatography coupled with tandem mass spectrometry (LC-MS). Both the Pooling Project ${ }^{13}$ and the $\mathrm{CCHS}^{6}$ used DiaSorin Liaison TOTAL 25(OH)D chemiluminescent immunoassay for measuring both 25(OH)D2 and 25(OH)D3. It is known that radioimmunoassay $(\mathrm{RIA})$ and chemiluminescent immunoassay (CLIA) measurements of 25(OH)D (e.g.) differ from chemical based measurements (e.g. High Performance Liquid Chromatography (HPLC) or LC-MS) of $25(\mathrm{OH}) \mathrm{D}$ by up to $18 \%{ }^{14}$. Two study results (CCHS ${ }^{6}$ and the Pooling Project ${ }^{9}$ ) which used the same measurement technique (DiaSorin Liaison 25(OH)D TOTAL) gave different results, which measures both 25-hydroxyvitamin D3 $\left(25(\mathrm{OH}) \mathrm{D}_{3}\right)$ and 25-hydroxyvitamin D2 $\left(25(\mathrm{OH}) \mathrm{D}_{2}\right)$. The EPIC study ${ }^{8}$ was the only study to use LC-MS to assess vitamin D status, using only the $25(\mathrm{OH}) \mathrm{D}_{3}$ measurement in the analysis as $25(\mathrm{OH}) \mathrm{D}_{2}$ was not detectable in most samples. It is unlikely that the inclusion of $25(\mathrm{OH}) \mathrm{D}_{2}$ in some of the analyses, but not others explains any difference in results between-studies as $25(\mathrm{OH}) \mathrm{D}_{2}$ is usually present in much lower concentrations than $25(\mathrm{OH}) \mathrm{D}_{3}$ in human blood, and most likely has lower biological efficacy ${ }^{15}$. Some differences between study results may be due to differences in study follow up times. For instance, the CCHS cohort had a relatively long follow-up (28 years) and showed a statistically significant result, as did HPFS and NHS studies (22 years), which showed a significant reduction in risk with increasing $25(\mathrm{OH}) \mathrm{D}$ 
concentration (pooled data for both cohorts only). A longer follow up time may render the baseline $25(\mathrm{OH}) \mathrm{D}$ measurement less representative of the persons vitamin $\mathrm{D}$ status closer to the time of diagnosis. This must be borne in mind when interpreting the results for the studies with longer follow-up times.

All studies controlled for season of blood collection using either residual adjustment ${ }^{6,9}$ or trigonometric functions ${ }^{8}$ in the models, and also all studies controlled for main potential confounders including BMI and smoking. The Pooling project ${ }^{9}$ adjusted for hypertension and in a sub analysis in $\mathrm{EPIC}^{8}$, adjustment for hypertension did not modify the results. The $\mathrm{CCHS}^{6}$, with a small number of cases, did not adjust for hypertension.

The proportion of current and former smokers was highest in the Pooling Project, with $37 \%$ of kidney cancer cases coming from participants in the ATBC cohort ${ }^{9}$. Smokers may have an increased risk of kidney cancer but also have a lower level of circulating $25(\mathrm{OH}) \mathrm{D}^{16}$. In the ATBC cohort, median circulating $25(\mathrm{OH})$ levels $(31.6 \mathrm{nmol} / \mathrm{L}$ in the controls) were lower than the average in the overall study populations. After exclusion of the ATBC participants from the Vitamin D Pooling project analyses, a U shape relationship was suggested with odds ratios of $0.75(95 \% \mathrm{Cl}: 0.40-1.41)$ for $<25 \mathrm{nmol} / \mathrm{L}$ and $0.57(95 \% \mathrm{Cl}: 0.27,1.17)$ for $\geq 100 \mathrm{nmol} / \mathrm{L}$ compared to $50-75 \mathrm{nmol} / \mathrm{L}$. In the Pooling Project, high 25(OH)D concentrations ( $\geq 75 \mathrm{nmol} / \mathrm{L})$ were associated with a non-statistically significant increased risk of kidney cancer for males (OR : $1.52,95 \% \mathrm{Cl}: 0.95,2.41)$ compared with $50-<75 \mathrm{nmol} / \mathrm{L}$ (referent). These results remained similar when the cohort subjects from the ATBC were excluded. In contrast, among females, high concentrations of $25(\mathrm{OH}) \mathrm{D}$ were associated with a statistically significant decreased risk of kidney cancer (OR: $0.31,95 \% \mathrm{Cl}: 0.12,0.85)$ compared with $50-<75 \mathrm{~mol} / \mathrm{L}$, although, there was no statistical evidence of a sex-25(OH)D interaction $(P: 0.42)$. Of note, in the EPIC study the stratified odds ratios for a doubling in circulating $25(\mathrm{OH}) \mathrm{D}$ values were 0.79 (95\% Cl: $0.60-1.05)$ in never smokers, 0.70 (95\% Cl: $0.50-0.98)$ in former smokers but $0.93(0.69-1.26)$ in current smokers, suggesting a weaker association in current smokers. In other stratified analyses within the EPIC study, strongest inverse associations with circulating 
$25(\mathrm{OH}) \mathrm{D}$ levels were observed among the obese participants but there was no significant interaction with BMI, smoking, sex or other factors investigated.

\subsection{Conclusion}

There is no clear explanation for the inconsistent results seen in this review, but differences in study populations and specifically the prevalence of smoking might partially explain it. For instance, EPIC and the CCHS were in European populations, whereas the Pooling Project included populations from Asia, Europe and USA. This review is limited by the small number of studies in the review and the possibility of publication bias. Overall, the existing evidence does not rule out a possible beneficial effect of adequate vitamin $D$ status against kidney cancer development. 


\section{References}

1. Ferlay J SI, Ervik M, Dikshit R, Eser S, Mathers C, Rebelo M, Parkin DM, Forman D, Bray, F. GLOBOCAN 2012 v1.0, Cancer Incidence and Mortality Worldwide: IARC CancerBase No. 11 [INTERNET] 2013 [cited Accessed 20/02/2015]; Available from: http://globocan.iarc.fr

2. Znaor A, Lortet-Tieulent J, Laversanne M, Jemal A, Bray F. International variations and trends in renal cell carcinoma incidence and mortality. European urology. 2015; 67(3): 519-30.

3. Chow WH, Dong LM, Devesa SS. Epidemiology and risk factors for kidney cancer. Nature reviews Urology. 2010; 7(5): 245-57.

4. Feldman D, Krishnan AV, Swami S, Giovannucci E, Feldman BJ. The role of vitamin $D$ in reducing cancer risk and progression. Nature reviews Cancer. 2014; 14(5): 342-57.

5. Karami S, Boffetta $P$, Stewart $P$, Rothman N, Hunting KL, Dosemeci M, et al. Occupational sunlight exposure and risk of renal cell carcinoma. Cancer. 2010; 116(8): 200110.

6. Afzal S, Bojesen SE, Nordestgaard BG. Low plasma 25-hydroxyvitamin D and risk of tobacco-related cancer. Clinical chemistry. 2013; 59(5): 771-80.

7. Joh HK, Giovannucci EL, Bertrand KA, Lim S, Cho E. Predicted plasma 25hydroxyvitamin D and risk of renal cell cancer. Journal of the National Cancer Institute. 2013; 105(10): 726-32.

8. Muller DC, Fanidi A, Midttun O, Steffen A, Dossus L, Boutron-Ruault MC, et al. Circulating 25-hydroxyvitamin D3 in relation to renal cell carcinoma incidence and survival in the EPIC cohort. American journal of epidemiology. 2014; 180(8): 810-20.

9. Gallicchio L, Moore LE, Stevens VL, Ahn J, Albanes D, Hartmuller V, et al. Circulating 25-hydroxyvitamin D and risk of kidney cancer: Cohort Consortium Vitamin D Pooling Project of Rarer Cancers. American journal of epidemiology. 2010; 172(1): 47-57.

10. Mondul AM, Weinstein SJ, Moy KA, Mannisto S, Albanes D. Vitamin D-binding protein, circulating vitamin $D$ and risk of renal cell carcinoma. International journal of cancer Journal international du cancer. 2014; 134(11): 2699-706.

11. Bischoff-Ferrari HA. Optimal serum 25-hydroxyvitamin D levels for multiple health outcomes. Advances in experimental medicine and biology. 2014; 810: 500-25.

12. Hamling J, Lee $P$, Weitkunat $R$, Ambuhl M. Facilitating meta-analyses by deriving relative effect and precision estimates for alternative comparisons from a set of estimates presented by exposure level or disease category. Statistics in medicine. 2008; 27(7): 954-70.

13. Gallicchio L, Helzlsouer KJ, Chow WH, Freedman DM, Hankinson SE, Hartge P, et al. Circulating 25-hydroxyvitamin D and the risk of rarer cancers: Design and methods of the 
Cohort Consortium Vitamin D Pooling Project of Rarer Cancers. American journal of epidemiology. 2010; 172(1): 10-20.

14. Carter GD, Berry JL, Gunter E, Jones G, Jones JC, Makin HL, et al. Proficiency testing of 25-hydroxyvitamin $\mathrm{D}(25-\mathrm{OHD})$ assays. The Journal of steroid biochemistry and molecular biology. 2010; 121(1-2): 176-9.

15. Tripkovic L, Lambert H, Hart K, Smith CP, Bucca G, Penson S, et al. Comparison of vitamin D2 and vitamin D3 supplementation in raising serum 25-hydroxyvitamin D status: a systematic review and meta-analysis. The American journal of clinical nutrition. 2012; 95(6): 1357-64.

16. Cutillas-Marco E, Fuertes-Prosper A, Grant WB, Morales-Suarez-Varela M. Vitamin D deficiency in South Europe: effect of smoking and aging. Photodermatology, photoimmunology \& photomedicine. 2012; 28(3): 159-61. 


\section{Legends for Tables and Figures}

Table 1: Studies on circulating 25(OH)D concentration and kidney cancer incidence identified in systematic review

Figure 1: Flow chart of the search for articles on vitamin D status and kidney cancer-

PubMed inception to $1^{\text {st }}$ December 2014

Figure 2: Association between circulating 25(OH)D and kidney cancer.

Note for figure 2: *Reference category changed so risk is for a $50 \%$ increase in $25(\mathrm{OH}) \mathrm{D}$ rather than a $50 \%$ decrease ${ }^{* *}$ Reference category was changed to $<25 \mathrm{nmol} / \mathrm{L}$ and the top two categories pooled to produce a cut-off point of $=>75 \mathrm{nmol} / \mathrm{L}{ }^{* \star *} \mathrm{ATBC}$; CLUE; CPS-II; MEC; NYU-WHS; PLCO; SMHS/SWHS *** Matched control data displayed here; combined control data gave a statistically significant effect $(\mathrm{OR}=0.82(0.68,0.99))$. 
Table 1

\begin{tabular}{|c|c|c|c|c|c|c|c|c|c|c|c|c|c|c|c|}
\hline $\begin{array}{l}\text { Author, } \\
\text { year }\end{array}$ & $\begin{array}{l}\text { Country, } \\
\text { design }\end{array}$ & $\begin{array}{l}\text { Study } \\
\text { name }\end{array}$ & $\begin{array}{l}25(\mathrm{OH}) \mathrm{D} \\
\text { Measure, } \\
\text { ratio } \pm\end{array}$ & $\begin{array}{l}\text { Method } \\
\text { 25(OH)D }\end{array}$ & $\begin{array}{l}\text { Form of } \\
25(\mathrm{OH}) \mathrm{D}\end{array}$ & Cases & $\begin{array}{l}\text { Years } \\
\text { follow } \\
\text { up }\end{array}$ & Type & Sex & Ratio & $\mathbf{L C l}$ & $\mathrm{UCl}$ & $\begin{array}{l}\text { Contrast } \\
\text { vs. Low) }\end{array}$ & $\begin{array}{l}\text { Controls } \\
\text { matched to } \\
\text { cases by: }\end{array}$ & $\begin{array}{l}\text { Data } \\
\text { adjustments }\end{array}$ \\
\hline $\begin{array}{l}\text { Afzal et al. } \\
2013^{6}\end{array}$ & $\begin{array}{l}\text { Denmark, } \\
\text { Prospective } \\
\text { cohort }\end{array}$ & $\mathrm{CCHS}$ & $\begin{array}{l}\text { Plasma } \\
25(O H) D \\
\text { HR }\end{array}$ & $\begin{array}{l}\text { DiaSorin } \\
\text { Liaison } \\
\text { TOTAL } \\
\text { CLIA }\end{array}$ & D2/D3 & 55 & 28 & $\mathrm{KC}$ & $\begin{array}{l}\mathrm{M} / \\
\mathrm{W}\end{array}$ & 0.75 & 0.58 & 0.96 & $\begin{array}{l}50 \% \text { reduction in } \\
25(\mathrm{OH}) \mathrm{D} \text { no vs. } \\
\text { yes (referent) }\end{array}$ & - & $\begin{array}{l}\text { Age, sex, } \\
\text { smoking, BMI, } \\
\text { alcohol, leisure } \\
\text { time and work- } \\
\text { related } \\
\text { physical } \\
\text { activity, } \\
\text { education. }\end{array}$ \\
\hline \multirow[t]{3}{*}{$\begin{array}{l}\text { Gallicchio } \\
\text { et al. } 2014^{9}\end{array}$} & \multirow{3}{*}{$\begin{array}{l}\text { Various, } \\
\text { Nested Case } \\
\text { control }\end{array}$} & \multirow{3}{*}{$\begin{array}{l}\text { Pooling } \\
\text { Project of } \\
\text { Rarer } \\
\text { Cancers d }\end{array}$} & \multirow{3}{*}{$\begin{array}{l}\text { Serum and } \\
\text { Plasma } \\
25(\mathrm{OH}) \mathrm{D}, \\
\text { OR }\end{array}$} & \multirow{3}{*}{$\begin{array}{l}\text { DiaSorin } \\
\text { Liaison } \\
\text { TOTAL } \\
\text { CLIA }\end{array}$} & \multirow[t]{3}{*}{ D2/D3 } & \multirow[t]{3}{*}{775} & \multirow[t]{3}{*}{$\begin{array}{l}2.2- \\
10.9\end{array}$} & $\mathrm{RCC}$ & $\begin{array}{l}\mathrm{M} / \\
\mathrm{W}\end{array}$ & 1.18 & 0.63 & 2.22 & \multirow{3}{*}{$\begin{array}{l}\geq 75 \quad \mathrm{nmol} / \mathrm{L} \quad \mathrm{vs} . \\
<25 \mathrm{nmol} / \mathrm{L} \\
\text { (referent) }\end{array}$} & \multirow[t]{3}{*}{$\begin{array}{l}\text { Age, sex, race, } \\
\text { and season }\end{array}$} & \multirow{3}{*}{$\begin{array}{l}\text { Education, } \\
\text { BMI, smoking } \\
\text { status, } \\
\text { hypertension, } \\
\text { diabetes, } \\
\text { height, alcohol }\end{array}$} \\
\hline & & & & & & & & $\mathrm{KC}$ & $M$ & 1.46 & 0.78 & 2.72 & & & \\
\hline & & & & & & & & & W & 0.47 & 0.12 & 1.90 & & & \\
\hline \multirow[t]{4}{*}{$\begin{array}{l}\text { Joh et al. } \\
2013^{7}\end{array}$} & \multirow[t]{4}{*}{$\begin{array}{l}\text { USA, } \\
\text { Prospective } \\
\text { cohort }\end{array}$} & \multirow[t]{2}{*}{ NHS } & \multirow[t]{2}{*}{$\begin{array}{l}\text { Predicted } \\
25(\mathrm{OH}) \mathrm{D}_{\mathrm{e}} \\
\mathrm{HR}\end{array}$} & \multirow[t]{2}{*}{ Predicted } & \multirow[t]{2}{*}{-} & \multirow[t]{2}{*}{201} & \multirow[t]{2}{*}{22} & \multirow[t]{2}{*}{$\mathrm{RCC}$} & \multirow[t]{2}{*}{ W } & 0.60 & 0.35 & 1.02 & $\begin{array}{l}80 \mathrm{nmol} / \mathrm{L} \text { vs.56 } \\
\mathrm{nmol} / \mathrm{L} \text { (referent) }\end{array}$ & \multirow[t]{4}{*}{-} & \multirow{4}{*}{$\begin{array}{l}\text { Age, } \\
\text { smoking } \\
\text { status, history } \\
\text { of } \\
\text { hypertension } \\
\text { and diabetes, } \\
\text { and parity }(\mathrm{F})\end{array}$} \\
\hline & & & & & & & & & & 0.70 & 0.45 & 1.07 & $\begin{array}{l}\text { Per } 10 \mathrm{ng} / \mathrm{mL}^{*} \\
\text { increment }\end{array}$ & & \\
\hline & & \multirow[t]{2}{*}{ HPFS } & \multirow[t]{2}{*}{$\begin{array}{l}\text { Predicted } \\
25(\mathrm{OH}) \mathrm{D} \text { e } \\
\mathrm{HR}\end{array}$} & \multirow[t]{2}{*}{ Predicted } & \multirow[t]{2}{*}{-} & \multirow[t]{2}{*}{207} & \multirow[t]{2}{*}{22} & \multirow[t]{2}{*}{ RCC } & \multirow[t]{2}{*}{$M$} & 0.66 & 0.40 & 1.09 & $\begin{array}{l}70 \mathrm{nmol} / \mathrm{L} \text { vs. } 50 \\
\mathrm{nmol} / \mathrm{L} \text { (referent) }\end{array}$ & & \\
\hline & & & & & & & & & & 0.61 & 0.35 & 1.04 & $\begin{array}{l}\text { Per } 10 \mathrm{ng} / \mathrm{mLb} \\
\text { increment }\end{array}$ & & \\
\hline $\begin{array}{l}\text { Muller et al. } \\
2014^{8}\end{array}$ & $\begin{array}{l}\text { Europe, } \\
\text { Nested Case } \\
\text { Control }\end{array}$ & EPIC & $\begin{array}{l}\text { Plasma } \\
25(\mathrm{OH}) \mathrm{D} \\
\text { OR }\end{array}$ & LC-MS & $\begin{array}{l}\text { D3 } \\
\text { (D2 } \\
\text { undetect } \\
\text { able) }\end{array}$ & 560 & 6.7 & $\mathrm{RCC}$ & $\begin{array}{l}\mathrm{M} / \\
\mathrm{W}\end{array}$ & 0.81 & 0.65 & 1.00 & $\begin{array}{l}\text { Doubling in } \\
25(\mathrm{OH}) \mathrm{D} \text { yes vs. } \\
\text { no (referent) }\end{array}$ & $\begin{array}{l}\text { Country, sex, } \\
\text { date of blood } \\
\text { collection, birth } \\
\text { date }\end{array}$ & $\begin{array}{l}\text { Alcohol intake, } \\
\text { BMI, smoking }\end{array}$ \\
\hline
\end{tabular}

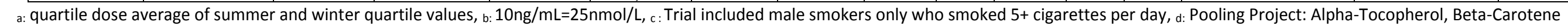

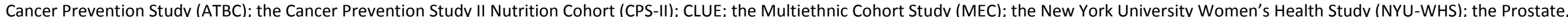

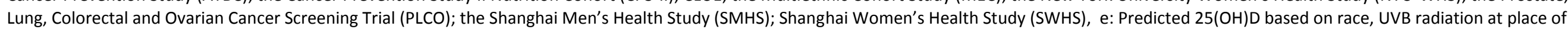
residence, leisure physical activity, BMI, dietary vitamin D, supplemental vitamin D, alcohol intake and use of postmenopausal hormone treatments (NHS only).

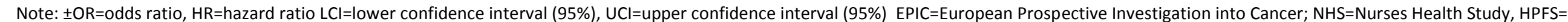
Health Professionals Follow-up Study, CCHS=Copenhagen City Heart Study. KC=mixed kidney cancer type, RCC=renal cell carcinoma 
Figure 1

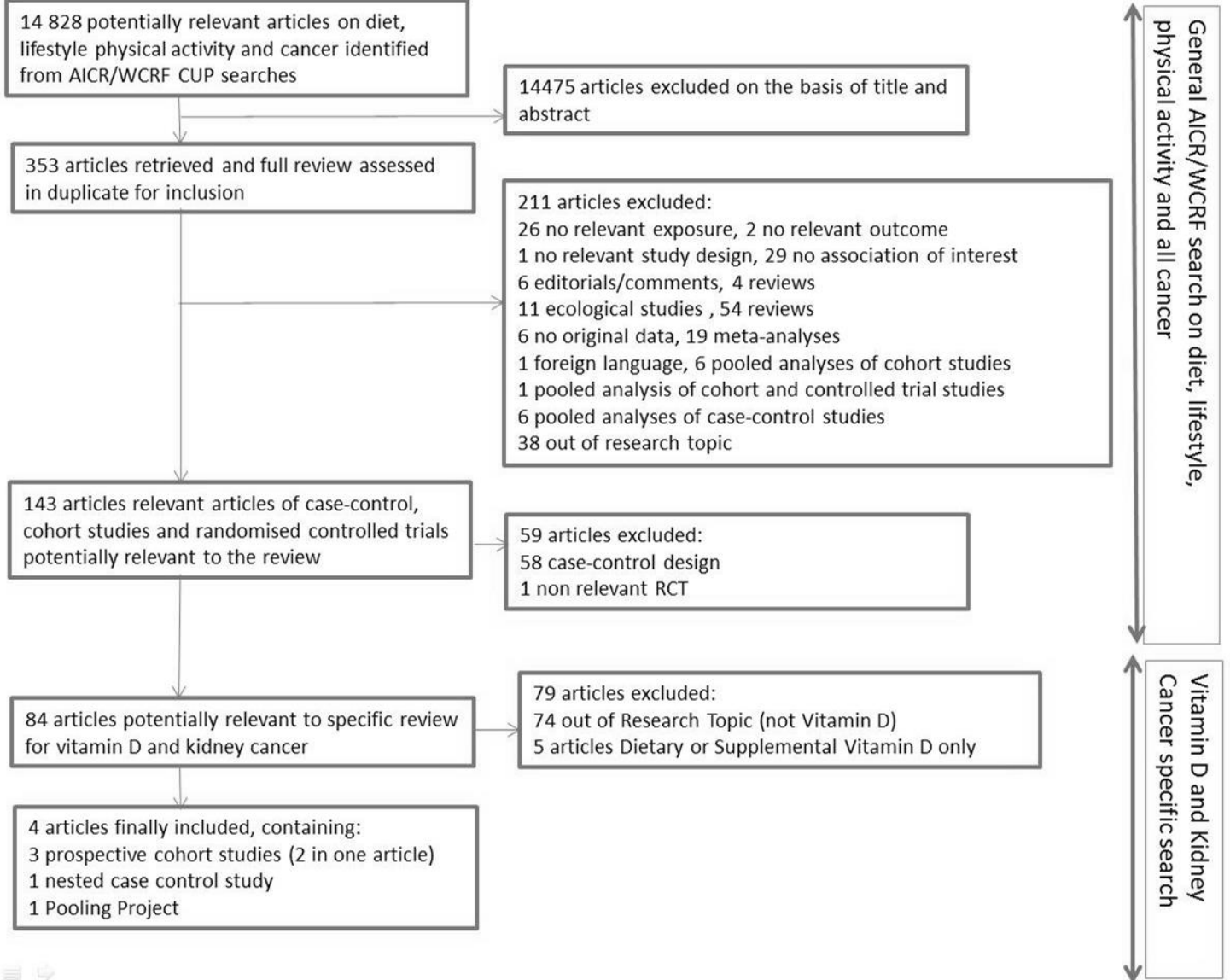


Figure 2

Author Year Sex Estimate (95\% Cl) Cohort Contrast

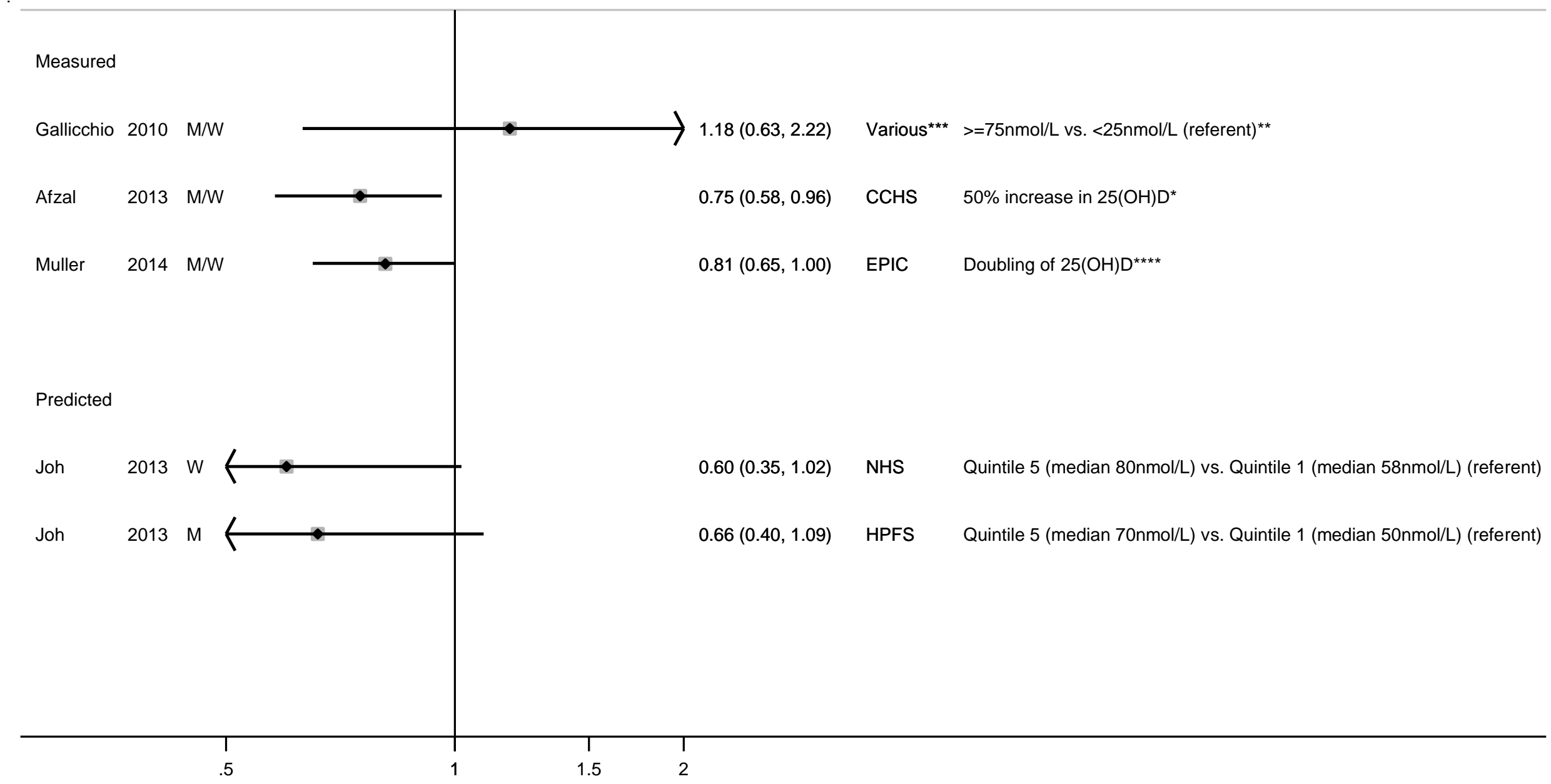

